\title{
PENGEMBANGAN SISTEM INFORMASI AKAD MUDHĀRABAH BANK SYARIAH BERBASIS DSS DENGAN MENGGUNAKAN METODE AHP
}

\author{
Setyo Budi Hartono, Jarot Dian Susatyono \& Abdul Kholiq ${ }^{1}$
}

\begin{abstract}
This research aims to develop a scoring system awarding financial cooperation that existed at Syariah Banking using various contract in it. The development of this system will replace the performance of the analytical assess and decide on the granting of the contract to mudharib. With this system will streamline the performance of the analysis in maximizing profits at BMT. Given the increased profitability for the results to be obtained by sabib al-mal will also increase. The methodology in this research is to analyze the process towards a needs assessment, process analysis and counting processes are the priorities of the system. This study resulted in a system that will be applied in analyzing the Mudharabah where deemed profitable or have a larger revenue share.
\end{abstract}

Keywords: Information system, Mudhārabah, DSS, AHP

\section{Pendahuluan}

Jumlah pengusaha di Indonesia diharapkan Pemerintah meningkat sedikitnya 500.000 dalam empat tahun ke depan. Program kewirausahaan di masa depan akan dirancang untuk menghasilkan wirausahawan kreatif, inovatif dan berdaya saing global. Pemerintah juga berharap pada tahun 2025 jumlah pengusaha akan berlipat menjadi 5 juta.

Saat ini, jumlah pengusaha di Indonesia adalah sekitar 0,24\% dari total penduduk. Sosiolog David McCleland (1985) mengatakan untuk menjadikan ekonomi suatu negara maju, jumlah pengusaha minimal $2 \%$ atau 4,8 juta pengusaha untuk jumlah penduduk Indonesia. Sebagai perbandingan, jumlah pengusaha di Singapura adalah 7,2\% dari total penduduk, Malaysia 2,1\%, Thailand 4,1\%, Korea Selatan 4,0\%, dan Amerika Serikat 11,5\%.

\footnotetext{
${ }^{1}$ UIN Walisongo Semarang, STEKOM PAT Semarang, dan UIN Walisongo Semarang
} 
Pengembangan Sistem Informasi...

Dibutuhkan waktu hingga tahun 2030 agar Indonesia memiliki 4,8 juta pengusaha atau $2 \%$ dari total penduduk saat ini. Ketika membicarakan rencana memulai usaha, hal pertama yang akan ditanyakan adalah "modal yang dibutuhkan?" karena sebagian besar orang beranggapan bahwa modal selalu identik dengan uang. Padahal, sebenarnya modal hanya memiliki persentase $10 \%$ dari semua modal yang dibutuhkan entrepreneur untuk memulai bisnisnya.

Untuk mendukung program pemerintah tersebut yang sesuai dengan keyakinan mayoritas warga yang ada Indonesia dan untuk meyakinkan bahwa bank syariah adalah lembaga keuangan mikro yang dioperasikan sesuai dengan prinsip keislaman. Sistem bagi hasil yang ada dalam ekonomi Islam akan mampu menumbuhkembangkan bisnis usaha mikro dalam rangka mengangkat derajat dan martabat serta membela kepentingan kaum fakir miskin, ditumbuhkan atas prakarsa dan modal awal dari tokoh-tokoh masyarakat setempat dengan berlandaskan pada sistem ekonomi yang saläm (keselamatan), berintikan keadilan, kedamaian dan kesejahteraan. Perbankan syariah adalah lembaga keuangan yang kegiatannya adalah menghimpun dan menyalurkan dana masyarakat yang bersifat profit motive.

Kegiatan bank syariah mengembangkan usaha-usaha produktif dan motivasi dalam meningkatkan kualitas kegiatan ekonomi pengusaha kecil bawah dan kecil, dengan antara lain mendorong kegiatan menabung dan menunjang pembiayaan kegiatan ekonominya, sedangkan kegiatan Baitul Mal menerima titipan dari dana zakat, infaq dan sedekah dan menjalankannya sesuai dengan peraturan dan amanahnya.

Dari pengertian-pengertian tersebut dapatlah ditarik suatu pengertian yang menyeluruh bahwa bank syariah merupakan organisasi bisnis yang juga beRp.eran sosial. Peran sosial bank syariah akan terlihat pada definisi Baitul Mal, sedangkan peran bisnis bank syariah terlihat dari akad kerjasamanya. Sebagai lembaga sosial, bank syariah harus didorong agar mampu beRp.eran secara profesional menjadi LAZ yang mapan.

Untuk menjamin profesionalisme dalam menjalankan bisnis, dibutuhkan pengembangan suatu sistem informasi. Sistem tersebut harus mampu mengakomodir kepentingan bisnis dengan mengefisienkan sisi biaya 
yang dapat menguntungkan bagi pengembangan bank syariah ke depan. Kerjasama melalui akad mudhärabah akan menjadi titik sentral bagi pertumbuhan ekonomi bank tersebut dengan memangkas mekanisme manual dan mengubahnya menjadi sistem informasi yang lebih efektif.

\section{Perumusan Masalah}

Masalah dalam penelitian di atas adalah berkaitan dengan efisiensi dalam menciptakan sistem untuk menciptakan bagi hasil yang lebih produktif. Maka perumusan masalahnya adalah:

1. Bagaimanakah pengembangan sistem informasi berbasis DSS dengan menggunakan metode APH ini bisa menggantikan analisis untuk penentuan akad mudhärabah pada Bank Syariah?

2. Bagaimanakah penggunaan sistem informasi berbasis DSS dengan menggunakan metode APH ini bisa mengurangi biaya dan meningkatkan efektifitas perolehan bagi hasil untuk Bank Syariah?

\section{Teori}

\section{Sistem Informasi}

Definisi sistem informasi, menurut Mc Leod, adalah suatu sistem di dalam suatu organisasi yang mempertemukan kebutuhan pengolahan transaksi harian yang mendukung fungsi organisasi yang bersifat manajerial dalam kegiatan strategi dari suatu organisasi untuk dapat menyediakan kepada pihak luar tertentu dengan laporan-laporan yang diperlukan. ${ }^{2}$

Pengertian sistem informasi menurut para ahli adalah sistem di dalam suatu organisasi yang mempertemukan kebutuhan pengolahan transaksi harian, membantu dan mendukung kegiatan operasi, bersifat manajerial dari suatu organisasi dan membantu mempermudah penyediaan laporan yang diperlukan. ${ }^{3}$

Sistem informasi adalah data yang dikumpulkan, dikelompokkan dan diolah ssehingga menjadi sebuah satu kesatuan informasi yang saling terkait

\footnotetext{
2 Tata Sutabri, Sistem Informasi Manajemen, Yogyakarta: Andi, 2005, hlm. 36.

${ }^{3}$ Erwan Arbie, Pengantar Sistem Informasi Manajemen, Edisi Ke-7, Jilid 1, Jakarta: Bina Alumni Indonesia, 2000, hlm. 35.
} 
Pengembangan Sistem Informasi...

dan saling mendukung sehingga menjadi suatu informasi yang berharga bagi yang menerimanya. ${ }^{4}$

Leitch Rosses mengemukakan sistem informasi adalah suatu sistem di dalam organisasi yang mempertemukan kebutuhan pengelolah transaksi harian, mendukung operasi, bersifat manajerial dan kegiatan strategi dari suatu organisasi dan menyediakan pihak luar tertentu dengan laporan-laporan yang diperlukan. ${ }^{5}$

Menurut Lani Sidharta, sebuah sistem informasi adalah sistem buatan manusia yang berisi himpunan terintegrasi dari komponen-komponen manual dan komponen-komponen terkomputerisasi yang bertujuan untuk mengumpulkan data, memproses data, dan menghasilkan informasi untuk pemakai. ${ }^{6}$

Sistem informasi didefinisikan Robert A. Leitch dan K. Roscoe Davis dalam buku Jogiyanto HM, sebagai "suatu sistem di dalam suatu organisasi yang mempertemukan kebutuhan pengolahan transaksi harian, mendukung operasi, bersifat manajerial dan kegiatan strategi dari suatu organisasi dan menyediakan pihak luar tertentu dengan laporan-laporan yang diperlukan."

Menurut Gordon B. Davis, sistem informasi adalah suatu sistem yang menerima masukan data dan instruksi, mengolah data tersebut sesuai dengan instruksi dan mengeluarkan hasilnya. ${ }^{8}$

\section{Decision Support Sistem (DSS)}

Dalam buku Turban, yang berjudul Introduction to Information Technology, disebutkan bahwa "Decision Support System (DSS) a computer-based that combines model and data to provide support for decision makers in solving semi structured or interdependent problems with extensive user involvement."

\footnotetext{
4 Tafri D. Muhyuzir, Analisa Perancangan Sistem Pengolahan Data, Cetakan Kedua, PT. Elex Media Komputindo, Jakarta, 2001, hlm. 8.

${ }^{5}$ Jogiyanto Hartono, Sistem Teknologi Informasi, Yogyakarta: Andi, 2005, hlm. 11 hlm. 11.

${ }^{6}$ Lani Sidharta, Pengantar Sistem Informasi Bisnis, Jakarta: P.T. ELEX Media Komputindo, 1995,

${ }^{7}$ Jogiyanto Hartono, Analisis dan Disain Informasi: Pendekatan Terstruktur Teori dan Praktek Aplikasi Bisnis,Yogyakarta: Andi Offset, 1999, hlm. 11.

8 Gordon B. Davis, Kerangka Dasar Sistem Informasi Manajemen Bagian 1, Jakarta: PT. Pustaka Binamas Pressindo, 1991, hlm. 91.

9 Turban E, Jaye Aronson, Peng-Liang Ting, Decision Support System and Intelegent. Andi. Yogyakarta, 2002, hlm. 321
} 
Decision Support System (DSS) atau Sistem Pendukung Keputusan (SPK) secara umum didefinisikan sebagai sebuah sistem yang mampu memberikan kemampuan baik kemampuan pemecahan masalah maupun kemampuan pemgkomunikasian untuk masalah semi-terstruktur. Secara khusus, SPK didefinisikan sebagai sebuah sistem yang mendukung kerja seorang manajer maupun sekelompok manajer dalam memecahkan masalah semi-terstruktur dengan cara memberikan informasi ataupun usulan menuju pada keputusan tertentu.

Pembuatan keputusan merupakan fungsi seorang manajer. Kegiatan pembuatan keputusan meliputi pengidentifikasian masalah, pencarian alternatif penyelesaian masalah, evaluasi dari alternatif-alternatif tersebut dan pemilihan alternatif keputusan yang terbaik. Kemampuan seorang manajer dalam membuat keputusan dapat ditingkatkan apabila ia mengetahui dan menguasai teori dan teknik pembuatan keputusan. Dengan peningkatan kemampuan manajer dalam pembuatan keputusan diharapkan dapat ditingkatkan kualitas keputusan yang dibuatnya, dan hal ini tentu akan meningkatkan efisiensi kerja manajer yang bersangkutan.

Pada awalnya, Turban \& Aronson mendefinisikan sistem penunjang keputusan (Decision Support Systems-DSS) sebagai sistem yang digunakan untuk mendukung dan membantu pihak manajemen melakukan pengambilan keputusan pada kondisi semi terstruktur dan tidak terstruktur. Pada dasarnya konsep DSS hanyalah sebatas pada kegiatan membantu para manajer melakukan penilaian serta menggantikan posisi dan peran manajer. ${ }^{10}$

Konsep DSS pertama kali diperkenalkan pada awal tahun 1970-an oleh Michael Scott Morton, yang dikenal dengan istilah "Management Decision System". Konsep DSS merupakan sebuah sistem interaktif berbasis komputer yang membantu pembuatan keputusan memanfaatkan data dan model untuk menyelesaikan masalah-masalah yang bersifat tidak terstruktur dan semi terstruktur. DSS dirancang untuk menunjang tahapan pembuatan keputusan, dimulai dari tahapan mengidentifikasi masalah, memilih data relevan, menentukan pendekatan yang digunakan dalam proses pembuatan keputusan sampai pada kegiatan mengevaluasi pemilihan alternatif.

${ }^{10}$ Ibid 
Pengembangan Sistem Informasi...

Pada dasarnya sistem pendukung keputusan adalah sistem yang tidak bisa dipisahkan dari teknologi komputer hampir mustahil ketika sistem pendukung keputusan tidak melibatkan teknologi didalam proses pengambil keputusannya yaitu komputer, secara umum sistem pendukung keputusan berfungsi untuk membantu dalam pengambilan keputusan secara efektif dimana nantinya permasalahan yang dihadapi dapat dengan cepat mendapat solusinya.

Menurut Kendal dan Kendal, Decision Support System (DSS) atau sistem pendukung keputusan hampir sama dengan sistem informasi manajemen tradisional karena keduanya sama-sama tergantung pada basisdata sebagai sumber data dimana DSS menekankan pada fungsi pendukung pembuatan keputusan diseluruh tahap-tahapnya, walaupun keputusan aktual masih tetap wewenang eksekutif sebagai pembuat keputusan. ${ }^{11}$ kredit: ${ }^{12}$

Tujuan dari sistem pendukung keputusan menganalisa pencairan

1. Membantu manajer dalam mengambil keputusan atas masalah semi terstuktur.

2. Memberikan dukungan atas pertimbangan manajer dan bukan dimaksudkan untuk menggantikan manajer.

Tahapan dalam Sistem Informasi Berbasis DSS ada enam tahapan adalah sebagai berikut :

1. Studi Literatur. Penulisan dimulai dengan studi kepustakaan yaitu proses pengumpulan bahan referensi dari buku, artikel, paper, jurnal, makalah, maupun situs internet mengenai DSS, metode AHP serta beberapa referensi lainnya untuk menunjang pencapaian tujuan penelitian).

2. Analisis Data dengan penelitian ke lapangan (field research). Pada tahap ini dilakukan penelitian yang bertujuan untuk memperoleh data secara langsung dari perusahaan khususnya bank melalui riset lapangan

a. Pengumpulan sampel dokumentasi yang berhubungan dengan masalah KUR pada BRI.

11 Kendall Keneth E, Kendal Julie E, Analisis dan Perancangan, Edisi lima, jilid 1, Jakarta: Gramedia, 2006.

12 Turban, Decision Support System.... 
b. Mewawancara pihak yang berkompeten dalam masalah KUR pada Bank.

3. Merancang Desain Sistem. Desain yang dirancang adalah desain user interface dan struktur program Sistem Pendukung Keputusan penentuan pemberian Kredit Usaha Rakyat.

4. Implementasi Sistem. Sistem diimplementasikan dalam bentuk perangkat lunak menggunakan bahasa pemrograman Visual Basic 6.0.

5. Pengujian dan Analisis Sistem. Pada tahap ini akan dilakukan pengujian sistem, untuk mencari kesalahan-kesalahan sehingga dapat diperbaiki. Kemudian akan dilakukan analisis terhadap fokus permasalahan penelitian, apakah sudah sesuai seperti yang diinginkan.

6. Dokumentasi Sistem. Pembuatan laporan Penelitian lengkap dengan analisis yang didapatkan.

3. Analitycal Hierarchy Process (AHP)

Pada dasarnya, proses pengambilan keputusan adalah memilih suatu alternatif. Analitycal Hierarchy Process (AHP) umumnya digunakan dengan tujuan untuk menyusun prioritas dari berbagai alternative pilihan yang ada dan pilihan-pilihan tersebut bersifat kompleks atau multikriteria. ${ }^{13}$

Penentuan prioritas inilah yang merupakan bagian penting dari penggunaan metode AHP. ${ }^{14}$ Selanjutnya Mulyono, menjelaskan bahwa pada dasarnya metode AHP merupakan suatu teori umum tentang suatu konsep pengukuran. Metode ini digunakan untuk menemukan suatu skala rasio baik dari perbandingan pasangan yang bersifat diskrit maupun kontinu. Perbandingan-perbandingan ini dapat diambil dari ukuran aktual atau dari suatu skala dasar yang mencerminkan kekuatan perasaan dan prefensi relatif.

Peralatan utama AHP adalah sebuah hirarki fungsional dengan input utamanya persepsi manusia akan prioritas antara satu elemen dengan elemen yang lainnya. Keberadaan hirarki memungkinkan dipecahnya masalah kompleks atau tidak terstruktur dalam sub-sub masalah, lalu menyusunnya menjadi suatu bentuk hirarki. Metode AHP yang dikembangkan oleh Thomas

\footnotetext{
${ }^{13}$ R. Bourgeois, Analitical Hierarchy Process: an Overview UNCAPSA-UNESCAP, Bogor, 2005.

14 Sri Mulyono, Teori Pengambilan Keputusan, Jakarta: Lembaga Penerbit Fakultas Ekonomi Indonesia, 1996.
} 
Pengembangan Sistem Informasi...

L. Saaty dapat memecahkan masalah kompleks, dimana kriteria yang diambil cukup banyak, struktur masalah yang belum jelas, ketidakpastian persepsi pembuat keputusan serta ketidakpastian tersedianya data statistik yang akurat. Adakalanya timbul masalah keputusan yang sulit untuk diukur secara kuantitatif dan perlu diputuskan secepatnya dan sering disertai dengan variasi yang beragam dan rumit sehingga data tersebut tidak mungkin dapat dicatat secara numerik karena data kualitatif saja yang dapat diukur yaitu berdasarkan pada persepsi, preferensi, pengalaman, dan intuisi.

Pada dasarnya terdapat beberapa langkah yang perlu diperhatikan dalam menggunakan metode AHP, antara lain: ${ }^{15}$

1. Mendefinisikan masalah dan menentukan solusi yang diinginkan.

2. Membuat struktur hirarki yang diawali dengan tujuan umum dilanjutkan dengan subtujuan, kriteria dan kemungkinan alternatif-alternatif pada tingkatan kriteria yang paling bawah.

3. Membuat matriks perbandingan beRp.asangan yang menggambarkan kontribusi relatif atau pengaruh setiap elemen terhadap masing-masing tujuan atau kriteria yang setingkat diatasnya. Perbandingan dilakukan berdasarkan judgment dari pembuat keputusan dengan menilai tingkat kepentingan suatu elemen dibandingkan elemen lainnya.

4. Melakukan perbandingan beRp.asangan sehingga diperoleh nilai judgment seluruhnya yaitu sebanyak $\mathrm{n} \times[(\mathrm{n}-1) / 2]$ buah dengan $\mathrm{n}$ adalah banyaknya elemen yang dibandingkan.

5. Menghitung nilai eigen dan mengujinya, jika tidak konsisten pengambilan data diulangi.

6. Mengulangi langkah 3, 4 dan 5 untuk seluruh tingkat hirarki.

7. Menghitung vektor eigen dari setiap matriks perbandingan beRp.asangan. Nilai vektor eigen merupakan bobot setiap elemen. Langkah ini untuk mensintesis judgment dalam penentuan prioritas elemen-elemen pada tingkat hirarki terendah sampai pencapaian tujuan.

8. Memeriksa konsistensi hirarki. Jika nilai lebih $10 \%$ atau 0,1 penilaian data harus diperbaiki

15 R. Suryadi dan M. Ali Ramdhani, Sistem Pendukung Keputusan, Bandung: PT. Remaja Rosdakarya, 1998. 


\section{Akad Mudhārabah}

Secara etimologis, mudhārabah diambil dari kata الضَرَبْ yang artinya melakukan perjalanan untuk berdagang. ${ }^{16}$ Dalam bahasa Arab mudhärabah berasal dari kata dha-ra-ba yang berarti memukul atau berjalan. Pengertian memukul atau berjalan ini lebih tepatnya yaitu proses seseorang memukulkan kakinya dalam menjalankan usaha. ${ }^{17}$ Mudhärabah atau qiradh ${ }^{18}$ termasuk dalam kategori syirkah ${ }^{19}$ atau kerjasama dengan cara sistem bagi hasil. Dalam alQur'an kata mudhārabah tidak disebutkan secara jelas dengan istilah mudhärabah. Al-Qur'an hanya menyebutkannya secara musytaq dari kata ضرَبَ yang diulang sebanyak 58 kali. ${ }^{20}$

Secara istilah, mudhärabah adalah akad kerja sama antara shāhib al-māl (pemilik modal) dengan mudhärib (yang mempunyai keahlian atau keterampilan) untuk mengelola suatu usaha yang produktif dan halal. Hasil dari penggunaan dana tersebut dibagi bersama berdasarkan nisbah yang disepakati, jika terjadi kerugian ditanggung shähib al-māl. ${ }^{21}$

Mudhärabah dalam perspektif fikih merupakan kontrak yang melibatkan antara dua kelompok, yaitu pemilik modal (investor) yang memercayakan modalnya kepada pengelola (mudhärib) untuk digunakan dalam aktifitas perdagangan. Sedangkan keuntungan dagang itu dibagi menurut kesepakatan bersama. ${ }^{22}$ Mudhärib dalam hal ini memberikan kontribusi pekerjaan, waktu dan mengelola usahanya sesuai dengan ketentuan yang dicapai dalam kontrak, salah satunya untuk mencapai keuntungan (profit) yang dibagi antara pihak

\footnotetext{
16 Ahmad Wardi Muslich, Fiqh Muamaalat, Jakarta: Amzah, 2010, h. 365

17 Muhammad Syafi'i Antonio, Bank Syariah: dari Teori ke Praktek, Jakarta Gema Insani, 2001, h. 95

18 Dalam bahasa Irak digunakan kata mudharabah, sedangkan penduduk Hijaz menyebutnya qiradh. Nurul Huda dan Mohamad Heykal, Lembaga Kenangan Islam Tinjanan Teoritis dan Praktis, Edisi Pertama, Jakarta: Kencana Prenada Media Group, 2010, h. 71

19 Syirkah adalah kerja sama dengan prinsip bagi hasil, produk pembiayaan syariah yang didasarkan atas prinsip bagi hasil yaitu pembiayaan mudhärabah dan musyārakah. Adiwarman Karim, Bank Islam Analisis Fiqih dan Kenangan, Jakarta: IIIT Indonesia, 2003, hlm. 90

${ }^{20}$ Nurul Huda dan Mohamad Heykal, Lembaga Kenangan Islam (Tinjanan Teoretis dan Praktis), Cet 1, Jakarta: Kencana, 2010, h. 71

21 Ibid, hlm. 72

22 M Ali Hasan, Berbagai Macam Transaksi dalam Islam (Fiqh Muamalat), Jakarta: Rajawali Pena, 2000, hlm. 169
} 
Pengembangan Sistem Informasi...

investor dan mudhärib berdasarkan proporsi yang telah disetuju bersama. Namun apabila terjadi kerugian yang menanggung adalah pihak investor saja. ${ }^{23}$

Mudhärabah menurut istilah pada dasarnya terdapat kesepakatan ulama dalam subtansi pengertian mudhärabah. Hanya saja terdapat beberapa variasi bahasa yang mereka gunakan dalam mengungkapkan definisi tersebut. Secara umum, variasi pengertian mudhärabah atau qiradh yang dikemukakan oleh para ulama sebagai berikut: ${ }^{24}$

Menurut para fukaha, mudhärabah ialah akad antara dua pihak (orang) saling menanggung, salah satu pihak menyerahkan hartanya kepada pihak lain untuk diperdagangkan dengan bagian yang telah ditentukan dari keuntungan, seperti setengah atau sepertiga dengan syarat-syarat yang telah ditentukan.

Menurut ulama Hanafiyah, mudhārabah adalah memandang tujuan dari pihak yang berakad yang berserikat dalam keuntungan (laba) karena harta diserahkan kepada yang lain dan yang lain punya jasa mengelola harta itu. Maka mudhärabah adalah akad syirkah dalam laba, satu pihak pemilik harta dan pihak lain pemilik jasa. Ulama Malikiyah beRp.endapat bahwa mudhärabah ialah akad perwalian, dimana pemilik harta mengeluarkan hartanya kepada yang lain untuk diperdagangkan dengan pembayaran yang ditentukan (mas dan perak). Imam Hanabilah berpendapat bahwa mudhärabah ialah ibarat pemilik harta menyerahkan hartanya dengan ukuran tertentu kepada orang yang berdagang dengan bagian dari keuntungan yang diketahui. Sementara itu, ulama Syafi'iyah berpendapat bahwa mudhärabah ialah akad yang menentukan seseorang menyerahkan hartanya kepada yang lain untuk ditijarahkan.

Lebih lanjut Wahbah Zuhaili beRp.endapat, mudhärabah adalah akad penyerahan modal oleh si pemilik kepada pengelola untuk diperdagangkan dan keuntungan dimiliki bersama antara keduanya sesuai dengan persyaratan yang mereka buat. ${ }^{25}$

Menurut Sayyid Sabiq sebagaimana dikutip oleh Ahmad Wardi, bahwa yang dimaksud dengan mudhärabah adalah suatu akad antara dua pihak dimana salah satu pihak memberikan uang (modal) kepada pihak lain untuk

\footnotetext{
23 Abdullah Saeed, Bank Islam dan Bunga, Yogyakarta: Pustaka Pelajar, 2004, hlm. 91

24 Hendi Suhendi, Fiqh Muamalah, Jakarta: PT. RajaGrafindo Persada, 2010, hlm. 136

25 Muslich, Fiqh Muamalat, hlm. 366
} 
diperdagangkan dengan ketentuan bahwa keuntungan dibagi di antara mereka berdua sesuai dengan kesepakatan mereka. ${ }^{26}$

Dari definisi tersebut dapat dipahami bahwa mudhārabah adalah suatu akad atau perjanjian antara dua orang atau lebih, dimana pihak pertama memberikan modal usaha, sedangkan pihak lain menyediakan tenaga dan keahlian dengan ketentuan bahwa keuntungan dibagi di antara mereka sesuai dengan kesepakatan yang mereka tetapkan bersama. Dengan kata lain dapat dikemukakan bahwa mudhärabah adalah kerja sama antara harta dengan tenaga atau keahlian.

Dengan demikian, dalam akad mudhärabah ada unsur syirkah atau kerja sama, hanya saja bukan kerja sama harta dengan harta ataupun tenaga dengan tenaga, melainkan antara harta dengan tenaga. Disamping itu, juga terdapat unsur syirkah (kepemilikan bersama) dalam keuntungan. Namun apabila terjadi kerugian maka kerugian tersebut ditanggung oleh pemilik modal, sedangkan pengelola tidak dibebani kerugian, karena ia telah rugi waktu, fikiran dan tenaga. ${ }^{27}$

Dalam istilah buku himpunan fatwa DSN (Dewan Syariah Nasional) dijelaskan bahwa yang dimaksud dengan pembiayaan mudhärabah adalah pembiayaan yang disalurkan oleh LKS kepada pihak lain untuk suatu usaha yang produktif. ${ }^{28}$

\section{Kerangka Pemikiran}

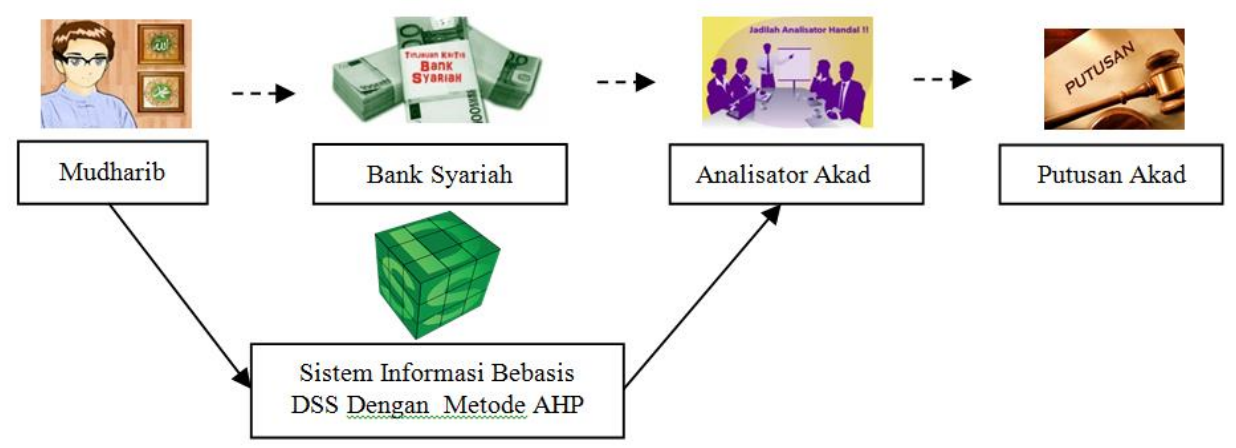

26 Ibid, h. 366

27 Hasan, Berbagai Macam..., hlm. 170

28 Majelis Ulama Indonesia, Himpunan Fatwa Dewan Syariah Nasional, Edisi Kedua, Jakarta: MUI 
Pengembangan Sistem Informasi...

\section{Model Penelitian Pengembangan}

Penelitian ini merupakan penelitian Riset dan Pengembangan (R\&D) dengan Model pengembangan Borg and Gall29 dengan 10 langkah. Meliputi:

1. Research and information collecting. Langkah ini antara lain studi literatur yang berkaitan dengan permasalahan yang dikaji meliputi penganalisaan kredit. Materi tersebut digunakan untuk merumuskan kerangka kerja penelitian; Di sini mengkaji penelitian yang sudah dilaksanakan. ${ }^{30}$

2. Planning; yaitu merumuskan permasalahan, menentukan tujuan, mendata produk yang dihasilkan, dan membuat prototype.

3. Develop preliminary form of product, yaitu mengembangkan bentuk permulaan dari produk yang akan dihasilkan berupa penganalisaan kredit dengan menggunakan sistem komputer berbasis DSS dengan menggunakan metode AHP. Termasuk dalam langkah ini adalah persiapan komponen pendukung, menyiapkan pedoman dan buku petunjuk, dan melakukan evaluasi terhadap kelayakan alat pendukung. Penyusunan instrumen validasi produk awal.

4. Preliminary field testing, yaitu melakukan ujicoba awal secara terbatas dalam skala terbatas. dengan melibatkan subjek secukupnya.

5. Main product revision, yaitu melakukan revisi atas dasar masukan dari para validator. Standar capaiannya adalah sistem informasi yang valid.

6. Main field testing, uji coba lapangan secara terbatas. Produk capaiannya adalah sistem informasi berbasis DSS untuk menganalisa pemberian kredit pembelajran dan bahan ajar yang implementasi terbatasnya praktis..

\section{Alat/Instrument Penelitian}

Menurut Ghozali, instrumen penelitian adalah semua alat yang digunakan untuk mengumpulkan, memeriksa, menyelidiki suatu masalah, atau mengumpulkan, mengolah, menganalisa dan menyajikan data-data secara

${ }^{29}$ Meredith D. Gall, Joyce P. Gall, dan Walter R. Borg, Educational Research An Introduction (4 ${ }^{\text {th }}$ ed.). New York: Pearson Education, Inc., 1983.

${ }^{30}$ Handoyo, "Perencanaan Sistem Evaluasi Kelayakan Pemberian Kredit Pada Pedagang Kecil Dan Menengah Di PT Centratama Nasional Bank", Thesis, Surabaya: Institut Teknologi Sepuluh Nopemb, 2004. 
sistematis serta obyektif dengan tujuan memecahkan suatu persoalan atau menguji suatu hipotesis. ${ }^{31}$

\section{Analisa Akad}

Untuk agunan dalam akad mudhārabah yaitu dengan usaha itu sendiri dan dengan jaminan BPKB. Untuk menghitung nilai motor tersebut digunakan analisa harga motor second di pasaran yaitu sebesar 50\% dari harga jual. Berikut ini adalah harga jual motor second di pasaran:

\begin{tabular}{|l|l|c|l|}
\hline \multicolumn{1}{|c|}{ Honda BeAT } & Honda Vario & Honda Scoopy & Yamaha Mio \\
\hline Tahun 2008 Rp.8 juta. & Tahun 2007 Rp.7,5 juta & Tahun 2010 Rp.9,5 juta & Tahun 2007 Rp.6 juta. \\
\hline Tahun 2009 Rp.8,7 juta & Tahun 2008 Rp.8 juta. & Tahun 2011 Rp.10 juta & Tahun 2008 Rp.6,5 juta \\
\hline Tahun 2010 Rp.9 juta & Tahun 2009 Rp.8,5juta & & Tahun 2009 Rp.7 juta. \\
\hline \multicolumn{1}{|c|}{ Supra X 125 } & Tahun 2010 Rp.9 juta & & Tahun 2010 Rp.7,5 juta \\
\hline Tahun 2008 Rp.8,5 juta & Tahun 2008 Rp.8,5 juta & Tahun 2008 Rp.7 juta & Tahun 2008 Rp.13 juta. \\
\hline Tahun 2009 Rp.9 juta. & Tahun 2009 Rp.9,5 juta & Tahun 2009 Rp.7,5 juta & Tahun 2009 Rp.14,5 jut \\
\hline $\begin{array}{l}\text { Tahun 2010 Rp.10,5 } \\
\text { juta }\end{array}$ & Tahun 2010 Rp.10 juta. & Tahun 2010 Rp.8 juta. & Tahun 2010 Rp.15,5 \\
\hline Tahun 2011 Rp.11 juta & Tahun 2011 Rp.10,5 jut & Tahun 2011 Rp.8,5 juta & Tahun 2011 Rp.16,5 juta \\
\hline
\end{tabular}

Skim Pencairan Akad Mudharabah pada Bank Syariah adalah sebagai berikut:

1. Jenis/Tujuan Penggunaan Akad: Tambahan Modal Kerja dan atau Investasi.

2. Kriteria Penerima: Mempunyai Usaha yang layak untuk diberikan tambahan kinerja keuangan Feasible namun belum bankable.

3. Persyaratan: Permohonan akad dilampiri dengan Surat Keterangan Usaha dari Kelurahan/Kepala Desa/Kepala Pasar, Fotokopi KTP dan Kartu Keluarga, Pas foto. Tidak sedang menerima kredit atau pembiayaan dari bank lain

4. Plafon: Maksimal Rp..100 juta (total eksposure)

${ }^{31}$ Imam Ghozali, Aplikasi Analisis Multivariate dengan Program SPSS, Semarang: Badan Penerbit Universitas Diponegoro, 2006, hlm. 144. 
Pengembangan Sistem Informasi...

5. Jangka Waktu: Modal Kerja: maks. 3 tahun, peRp.anjangan maks. 6 tahun ;Kredit Investasi: maks. 5 tahun, peRp.anjangan maks. 10 tahun (terhitung sejak tanggal perjanjian awal)

6. Suku Bunga:

Jangka waktu 6 bulan : suku bunga flat/bulan 1,085

Jangka waktu 12 bulan : suku bunga flat/bulan 1,025

Jangka waktu 18 bulan : suku bunga flat/bulan 1,015

Jangka waktu 24 bulan : suku bunga flat/bulan 1,020

Jangka waktu 36 bulan : suku bunga flat/bulan 1,040

Jangka waktu 48 bulan : suku bunga flat/bulan 1,065

Jangka waktu 60 bulan : suku bunga flat/bulan 1,095

7. Aggunan: Usaha yang dikelola calon debitur.

8. Bagi hasil 30\%:70\% dan bagi laba 10\%;90\%

\section{Metode dan Analisis DSS dengan Metode AHP}

Proses pembuatan perangkat lunak Sistem Pendukung Keputusan Penentu Akad Mudharabah, Bank Syariah dan analisator akad dilakukan dengan menggunakan model air terjun (Waterfall).

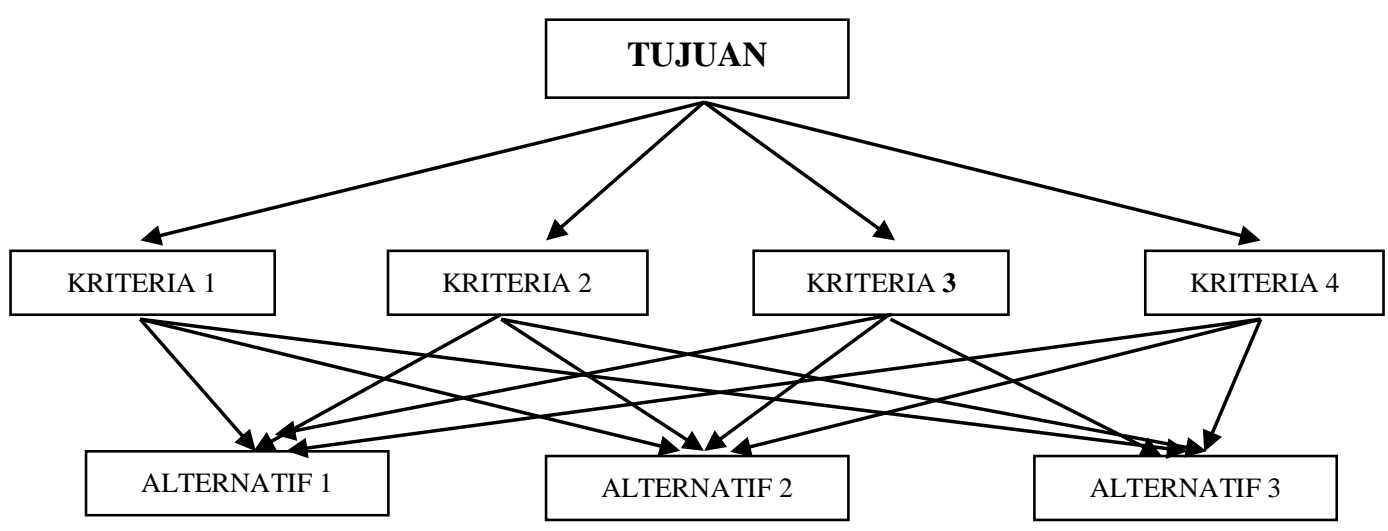


Dimana siklus perangkat lunak ini didefinisikan pada gambar 2.

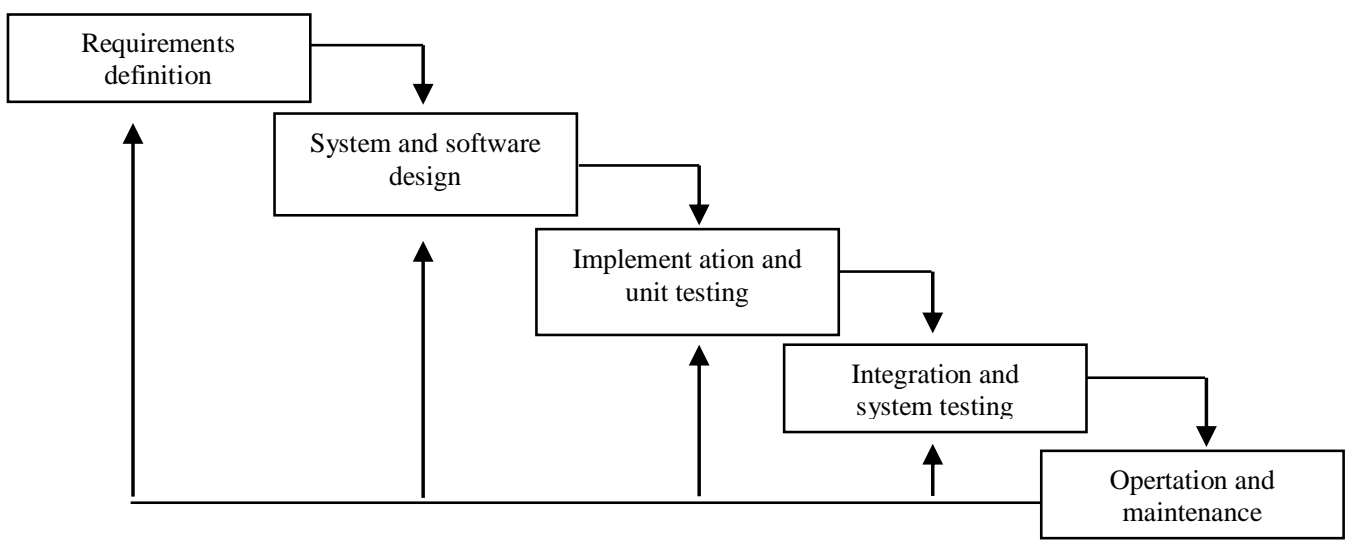

Tahapan-tahapan yang akan dilakukan untuk pengembangan dasar adalah sebagai berikut:

1. Analisis dan definisi persyaratan. Pada tahap ini akan dilakukan pengumpulan data, analisa kebutuhan, pembatasan masalah, tujuan dari pembuatan sistem dengan melakukan wawancara langsung serta pengambilan data Pegawai PT Bank Mandiri Syariah (BMS) Tbk.

2. Perancangan sistem dan perangkat lunak. Pada proses ini akan dilakukan perancangan menu sistem, modul-modul serta arsitektur sistem secara keseluruhan.

3. Implementasi dan pengujian unit. Pada tahap ini, akan dilakukan pembuatan pemrograman perangkat lunak (coding) dan pengujian perangkat lunak dengan memasukkan beberapa sample data.

4. Integrasi dan pengujian unit. Perangkat lunak akan diintegrasikan dan diuji sebagai sistem yang lengkap untuk menjamin bahwa persyaratan sistem sudah telah dipenuhi.

\section{Metode Pendekatan dan Pengembangan Sistem}

Metode pendekatan sistem dilakukan sebagai langkah untuk menghasilkan sistem informasi berbasis komputer untuk menyelesaikan permasalahan-permasalahan yang terdapat dan ditemukan pada tempat penelitian, yang dimana langkah selanjutnya aka dilakukan metode 
Pengembangan Sistem Informasi...

pengembangan sistem untuk mengembangkan sistem yang baru berdasarkan cara kerja sistem dan berdasarkan permasalahan yang ada.

\section{Metode Pendekatan Sistem}

Metode pendekatan sistem dengan berorientasi pada data dan proses untuk menghasilkan suatu sistem informasi yang terarah dan mampu untuk membantu dalam sistem pengambilan keputusan. Alat yang digunakan untuk membantu UML (Unified Modeling Language)pemodelan data adalah dengan menggunakan.

\section{Metode Pengembangan Sistem}

Dengan metode prototyping ini pengembang dan pelanggan dapat saling berinteraksi selama proses pembuatan sistem. Sering terjadi seorang pelanggan hanya mendefinisikan secara umum apa yang dikehendakinya tanpa menyebutkan secara detal output apa saja yang dibutuhkan, pemrosesan dan data-data apa saja yang dibutuhkan. Sebaliknya di sisi pengembang kurang memperhatikan efesiensi algoritma, kemampuan sistem operasi dan interface yang menghubungkan manusia dan komputer. Prototipe tersebut adalah sistem informasi yang menggambarkan hal-hal penting dari sistem informasi yang akan datang.

\section{Alat Bantu Analisis Perancangan}

Sejumlah sistem memiliki cara pemodelan, untuk mendeskripsikan gambaran sistem. Pada dasarnya kita dapat menggunakan model apa saja tergantung pada situasi. Perancangan sistem dapat dilakukan dengan bantuan Use Case Diagram, Sequence Diagram, System Sequence Diagram, Class Diagram, Conceptual class Diagram, Flowmap, Kamus Data.

1) Use case diagram dapat sangat membantu bila kita sedang menyusun requirement sebuah sistem, mengkomunikasikan rancangan dengan klien, dan merancang test case untuk semua feature yang ada pada sistem. Sebuah use case dapat meng-include fungsionalitas use case lain sebagai bagian dari proses dalam dirinya. Secara umum diasumsikan bahwa use case yang di-include akan dipanggil setiap kali use case yang meng-include dieksekusi secara normal. 
2) Class Diagram dapat merupakan implementasi dari sebuah interface, yaitu class abstrak yang hanya memiliki metoda. Interface tidak dapat langsung diinstansiasikan, tetapi harus diimplementasikan dahulu menjadi sebuah class.

3) Conceptual Class Diagram menggambarkan identifikasi kelas konseptual dengan atribut dan asosiasinya. Conceptual Class Diagram bertujuan untuk menjabarkan domain permasalahan menjadi domain model.

4) Sequence Diagram menggambarkan interaksi antar objek di dalam dan disekitar sistem (termasuk pengguna, display, dan sebagainya) berupa message yang digambarkan terhadap waktu. Sequence diagram terdiri atar dimensi vertical (waktu) dan dimensi horizontal (objek-objek yang terkait).

5) System Sequence Diagram menggambarkan interaksi antara objek dengan sebuah sistem yang utuh. Sistem Sequence Diagram digunakan untuk mengilustrasikan event sistem baru untuk menjelaskan operasi suatu sistem baru tersebut. Sistem Sequence Diagram menganalisis operasi sistem sehingga dapat mengidenntifikasikan input dan output utama event sistem.

6) Activity Diagram menggambarkan rangkaian aliran dari aktivitas, digunakan untuk mendeskripsikan aktifitas yang dibentuk dalam suatu operasi sehingga dapat juga digunakan untuk aktifitas lainnya seperti use caseatau interaksi.

\section{Pengujian Software}

Untuk mengidentifikasi apakah perangkat lunak yang dibangun telah sesuai dengan yang diharapkan, sesuai dengan kebutuhan dan untuk menguji perangkat lunak untuk menemukan kesalahan-kesalahan yang belum terungkap.

Metode pengujian perangkat lunak yang digunakan dalam penelitian ini adalah dengan menggunakan metode Black Box Testing. Black Box Testing adalah sebuah metode yang digunakan untuk menemukan kesalahan dan mendemonstrasikan fungsional aplikasi pada saat dioperasikan, apakah input diterima dengan benar dan output yang dihasilkan telah sesuai dengan yang diharapkan apakah integritas informasi eksternal teRp.elihara. 
Pengembangan Sistem Informasi...

Pengujian black box berusaha menemukan kesalahan dalam kategori sebagai adalah berikut.

1. Fungsi yang tidak benar atau tidak ada.

2. Kesalahan antarmuka.

3. Kesalahan dalam struktur data dan akses basis data.

4. Kesalahan kinerja (performansi).

5. Kesalahan Inisialisasi dan kesalahan terminasi.

Pengujian (testing) sistem informasi, terdapat beberapa langkahlangkah dalam pengujian, diantaranya:

a. Testing saat Input Data adalah tindakan untuk menguji edit dan kontrol dalam pemasukan data, misalnya : validasi, cek digit.

b. Testing saat Pemrosesan buntuk meyakinkan program bekerja seperti yang diharapkan.

c. Testing saat Output untuk meyakinkan bahwa laporan yang dihasilkan telah dibuat dengan format yang benar dan mempunyai informasi yang valid.

\section{Pembahasan}

Pengembangan Sistem Informasi Akad Mudhärabah Bank Syariah Berbasis DSS metode AHP:

a. Diagram Context Sistem Informasi Akad Mudharabah Bank Syariah

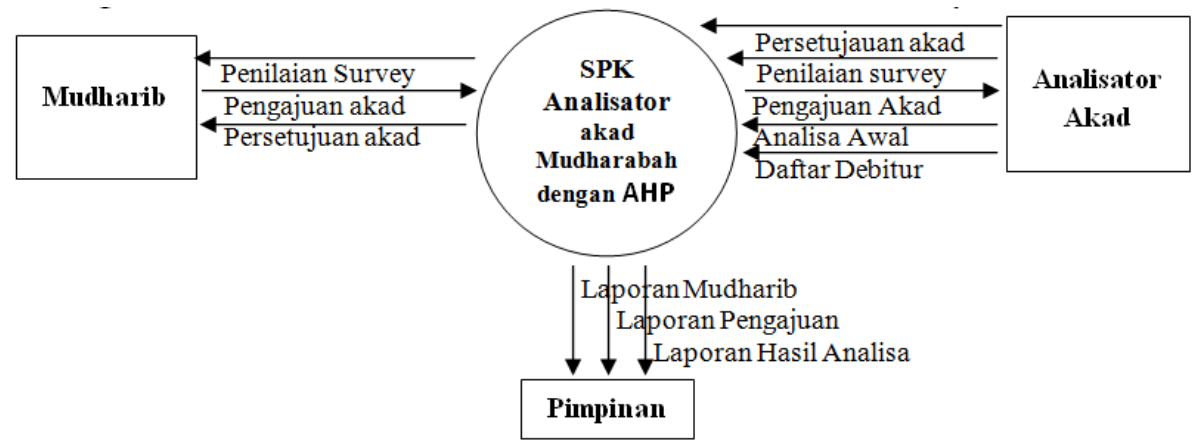

Gambar 1. Diagram Context 
b. DFD Level 0

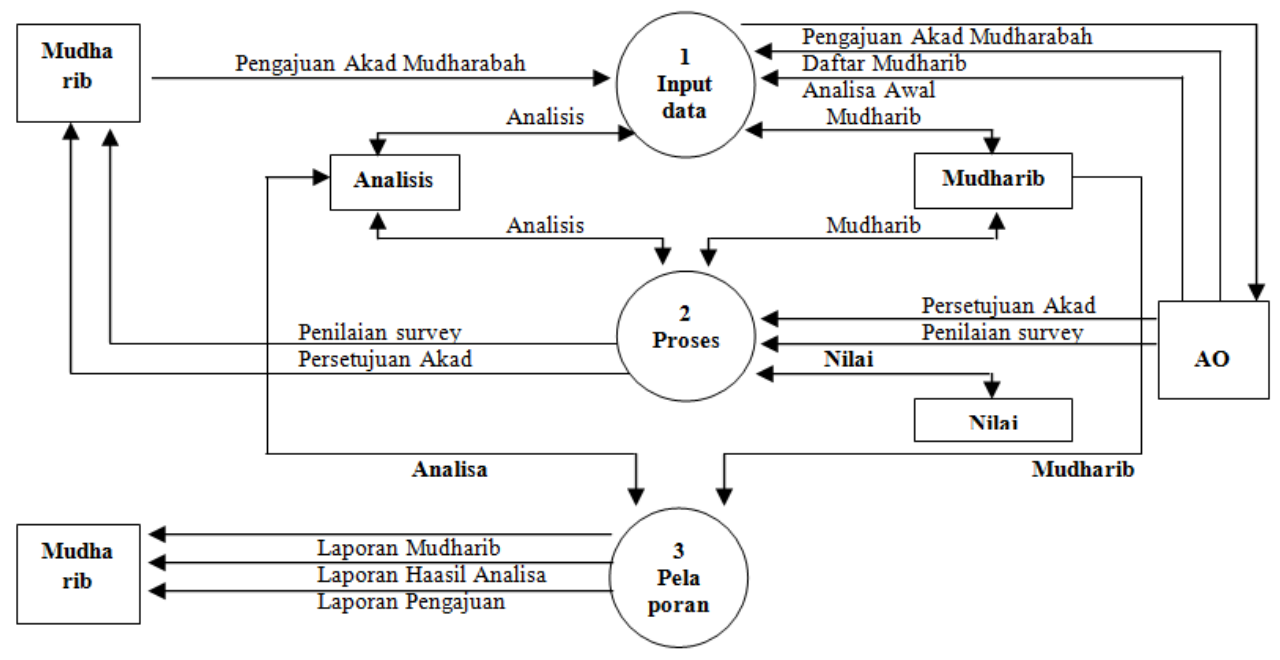

Gambar 2. DFD Level 0

c. Entity Relationship Diagram

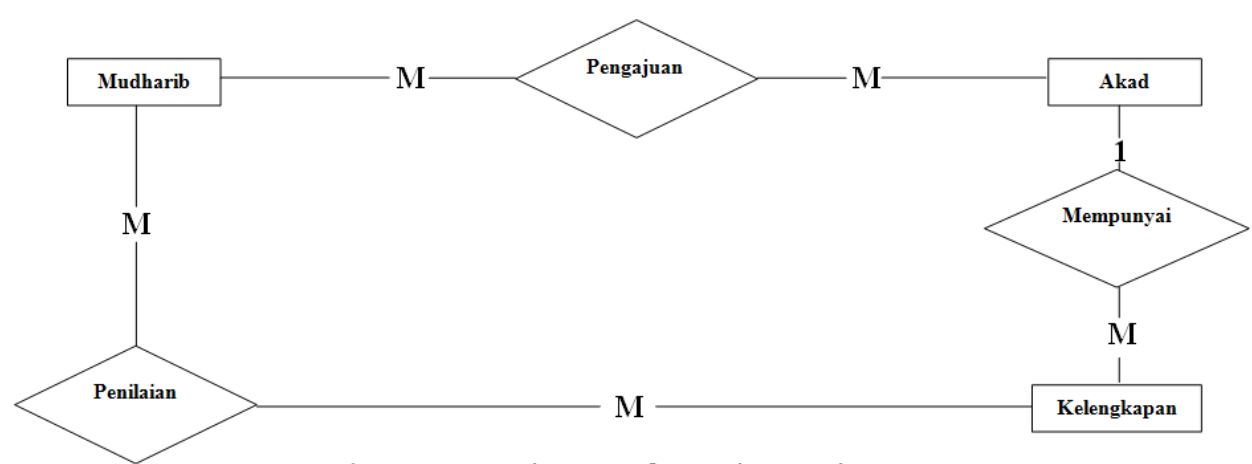

Gambar 3. ERD Sistem Informasi Mantri KUR

Dari ERD di atas memiliki struktur data sebagai berikut:

1) Debitur \{id_debitur, nama, alamat, jenis_kelamin, pekerjaan, usia, no_telp\}

2) Pengajuan \{tanggal_pengajuan, id_debitur, id_akad

3) Akad \{id_kredit, jenisakad, pinjaman, jangkawaktu\}

4) Kelengkapan \{id_debitur, tanggal_survey, petugas_survey, pasfoto, fotocopy_ktp, fotocopy_KK, fotocopy_suratnikah, fotocopy_kartupegawai, BPKB\} 
Pengembangan Sistem Informasi...

5) Penilaian \{tanggal_laporan, id_debitur, hasil_wawancara, hasil_survey, nilai_character, nilai_capital, nilai_capacity, nilai_condition, nilai_collateral, kesimpulan\}

d. Struktur Menu

Berikut ini merupakan struktur menu program Pengembangan Sistem Informasi Mantri KUR Berbasis DSS dengan Menggunakan Metode AHP:

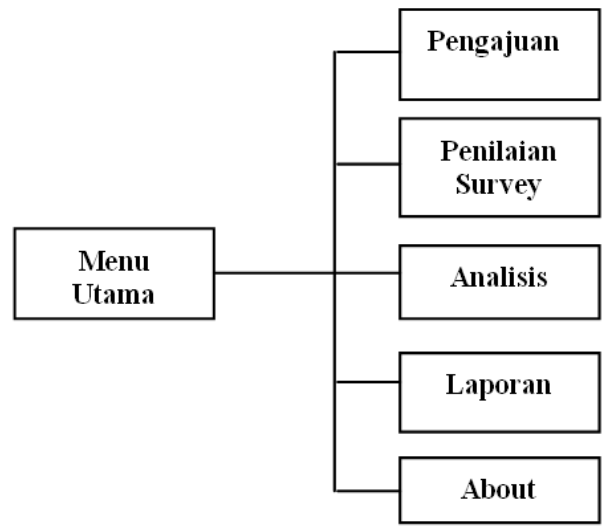

Gambar 4. Struktur Menu Sistem

e. Desain Input

1) Desain Form Pengajuan Debitur

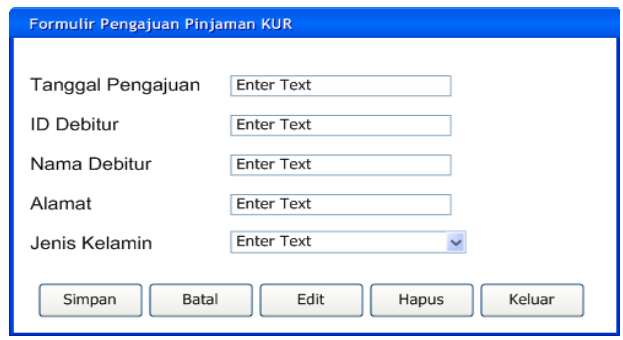

Gambar 5. Desain Form Pengajuan Debitur

Form ini digunakan untuk memasukkan data pengajuan kredit (debitur) yang di dalamnya terdiri dari tanggal pengajuan, ID Debitur, Nama debitur, alamat, dan juga jenis kelamin. 
2) Desain Form Kelengkapan Debitur

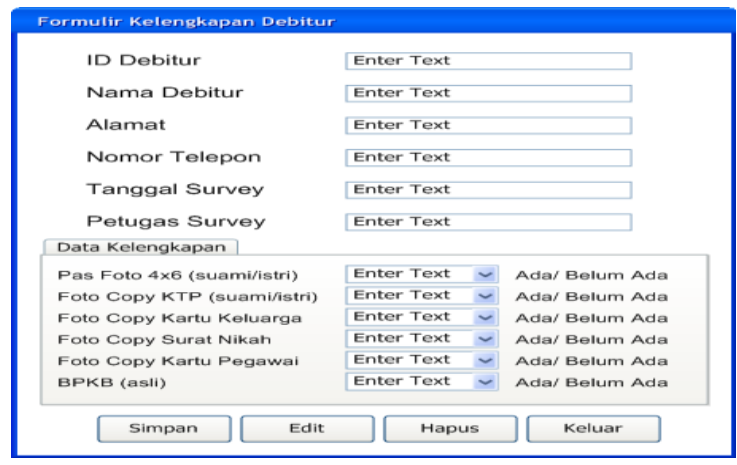

Gambar 6. Desain Form Kelengkapan Debitur

Form ini digunakan untuk mengisikan data-data kelengkapan dari debitur yang mengajukan Kredit. Kelengkapan yang diisikan ke dalam sistem ini sesuai dengan persyaratan utama dari pengajuan akad mudhārabah.

3) Form Penilaian Survey

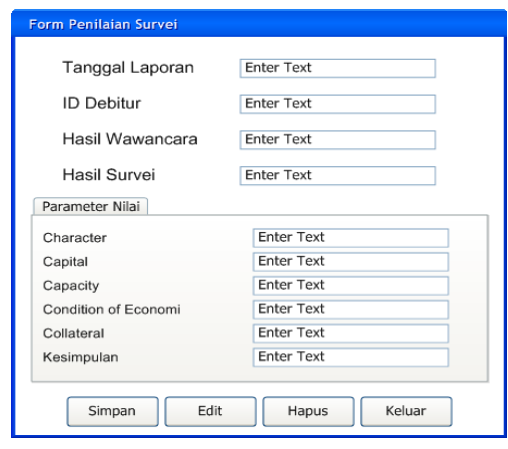

Gambar 7. Form Penilaian Survey

Form ini digunakan untuk memasukkan hasil penilaian berdasarkan survey yang dilakukan oleh petugas Bank Syariah yang melakukan survey ke debitur dan lingkungan yang ada di sekitar debitur.

4) Form Penilaian Kelayak Kredit

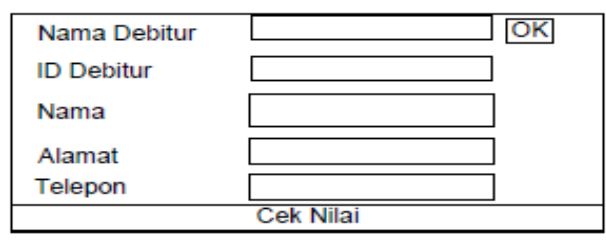

Gambar 8. Form Penilaian Kelayakan Kredit 
Pengembangan Sistem Informasi...

Pada form ini dilakukan penilaian kriteria, Jenis kriteria ini terdiri dari beberapa kategori, yaitu: Character, Capacity, Capital, Collateral, Condition, No, Sub Kriteria, Skor, Bobot, serta keterangan akan otomatis muncul setelah user memilih jenis kriteria. Lalu memilih tombol hasil untuk mengetahui hasil perhitungan karakter, serta untuk dilanjutkan ke perhitungan kriteria lainnya.

5) Form Hasil Penilaian

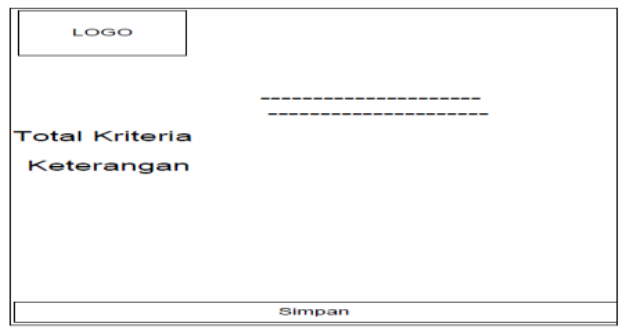

Gambar 9. Form Hasil Penilaian

Setelah user memilih tombol hasil, maka tampilan selanjutnya adalah hasil dari perhitungan kriteria-kriteria, pilih tombol simpan untuk menyimpan data.

Tampilan dari hasil akhir penilaian kelayakan, terdapat nama debitur dan keterangan layak atau tidaknya menerima layanan akad.

6) Hasil Pengujian Perhitungan Metode AHP

Tabel 1. Matriks Perbandingan Berpasangan

\begin{tabular}{|l|c|c|c|c|c|}
\hline & Condition of Economy & Character & Capital & Capacity & Collateral \\
\hline Condition of Economy & 1 & 0,33 & 0,25 & 0,20 & 0,50 \\
\hline Character & 3 & 1 & 0,25 & 0,33 & 0,20 \\
\hline Capital & 4 & 4 & 1 & 0,33 & 0,50 \\
\hline Capacity & 5 & 3 & 3 & 1 & 0,20 \\
\hline Collateral & 2 & 5 & 2 & 5 & 1 \\
\hline Jumlah & 15 & 13,33 & 6,50 & 6,87 & 2,40 \\
\hline
\end{tabular}

Angka 1 (sama pentingnya) pada Condition of Economy menggambarkan tingkat kepentingan yang sama antara Condition of Economy dengan Condition of Economy.

Angka 3 (sedikit lebih penting) pada kolom Character baris Capacity menggambarkan salah satu elemen sedikit lebih penting dibandingkan dengan elemen lainnya. 
Angka 4 (nilai tengah) pada kolom Character baris Capital menggambarkan terdapat keraguan dalam penilaian di antara dua tingkat elemen.

Angka 5 (lebih penting) pada kolom Character baris Collateral menggambarkan 1 elemen dominasinya sangat nyata daripada elemen pasangannya.

Angka 2 (nilai tengah) pada kolom Character baris Condition menggambarkan terdapat keraguan dalam penilaian di antara dua tingkat elemen.

Angka 0,33 dari kolom Capacity baris Character diperoleh dari perhitungan angka 1 pada kolom Character baris Character dibagi dengan angka 3 pada kolom Character baris Capacity.

Angka-angka yang terdapat pada kolom dan baris kriteria yang lain diperoleh dari cara yang sama.

7) Matriks Nilai Kriteria

Tabel 2. Matriks Kriteria

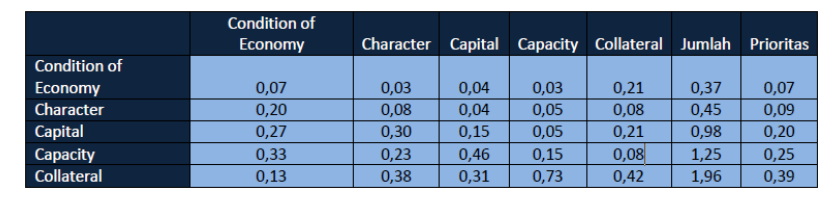

Nilai 0,07 pada kolom Condition of Cconomy baris Condition of Economy diperoleh dari perhitungan angka 1 pada kolom Condition of Cconomy baris Condition of Economy dibagi dengan jumlah kolom Condition of Economy (15).

Nilai pada kolom jumlah diperoleh dari perhitungan $0,07+0,03+0,04+0,03+0,21=0,37$

Nilai kolom prioritas diperoleh dari nilai pada kolom jumlah dibagi dengan jumlah kriteria. Dalam hal ini jumlah kriteria yaitu 5. Jadi: $0,37 / 5=0,07$

Angka-angka yang terdapat pada baris dan kolom yang lain diperoleh dari cara yang sama.

8) Matriks Penjumlahan Tiap Baris 
Pengembangan Sistem Informasi...

Tabel 3. Matriks Penjumlahan Tiap Baris

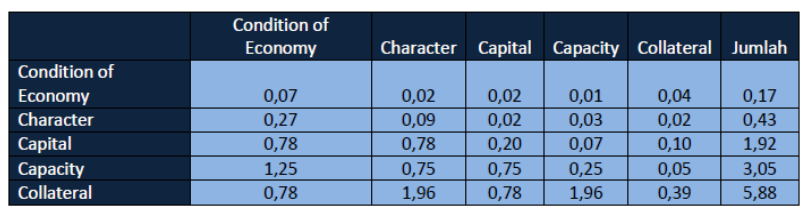

Nilai 0,07 pada kolom baris Condition of Economy diperoleh dari kolom prioritas $0,07 * 1$ (angka 1 diperoleh dari tabel matriks beRp.asangan baris Character kolom Character).

Nilai 0,27 pada kolom Condition of Economy baris Character diperoleh dari kolom prioritas $0,09 * 3$ (angka 3 diperoleh dari tabel matriks beRp.asangan baris Character kolom Condition of Economy).

Nilai 0,02 pada kolom Character baris Condition of Economy diperoleh dari kolom prioritas $0,07 * 0,33$ (angka 0,33 diperoleh dari tabel matriks beRp.asangan baris Condition of Economy kolom Character).

Nilai pada kolom jumlah diperoleh dari hasil penjumlahan $0,07+0,02+0,02+0,01+0,04=0,17$

Angka-angka pada baris dan kolom yang lain diperoleh dari hasil cara yang sama

\section{Kesimpulan}

Berdasarkan hasil analisa dan berdasarkan uraian yang telah dilakukan selama proses pelaksanaan pengerjaan aplikasi Pengembangan Sistem Informasi Akad Mudhārabah Bank Syariah Berbasis DSS Menggunakan Metode AHP, maka dapat diambil kesimpulan:

1. Merancang dan membangun sistem pendukung keputusan pengajuan akad, yang dapat membantu dalam proses pengambilan keputusan, layak atau tidaknya mudhārib diberi layanan akad.

2. Proses pengambilan keputusan menggunakan metode AHP.

3. Dengan dibangunnya sistem pendukung keputusan mampu mengatasi dan mengurangi permasalahan-permasalahan yang ada, sehingga proses pemberian kredit menjadi lebih cepat. 


\section{DAFTAR PUSTAKA}

Antonio, Muhammad Syafi'i, Bank Syariah: dari Teori ke Praktek, Jakarta: Gema Insani, 2001.

Arbie, E., Pengantar Sistem Informasi Manajemen, Edisi Ke-7, Jilid 1, Jakarta: Bina Alumni Indonesia, 2000.

Bourgeois, R., Analitical Hierarchy Process: an Overview UNCAPSAUNESCAP. Bogor, 2005.

Djumhana, Muhammad, Hukum Perbankan di Indonesia, PT. Citra Aditya Bakti, 2000.

Gall, Meredith D., Joyce P. Gall, dan Walter R. Borg, Educational Research An Introduction (4th ed.). New York: Pearson Education, Inc., 1983.

Ghozali, Imam, Aplikasi Analisis Multivariate dengan Program SPSS, Semarang: Badan Penerbit Universitas Diponegoro, 2006.

Gordon B. Davis, Kerangka Dasar Sistem Informasi Manajemen Bagian 1. Jakarta: PT. Pustaka Binamas Pressindo, 1991.

Handoyo, Perencanaan Sistem Evaluasi Kelayakan Pemberian Kredit Pada Pedagang Kecil Dan Menengah Di PT Centratama Nasional Bank. Thesis, Surabaya: Institut Teknologi Sepuluh Nopember, 2004.

Hartono, Jogiyanto, Analisis dan Disain Informasi: Pendekatan Terstruktur Teori dan Praktek Aplikasi Bisnis, Yogyakarta: Andi Offset, 1999.

---------, Sistem Teknologi Informasi, Yogyakarta: Andi, 2005.

Hasan, M Ali, Berbagai Macam Transaksi dalam Islam (Fiqh Muamalat), Jakarta: Rajawali Pena, 2000.

http:/ /yusufarif.blogspot.com/2011/09/menghitung bunga bank.html

http://www.master-exselen.com/2010/03/pengaruh bmt terhadap simtem. html

Huda, Nurul dan Muhamad Heykal, Lembaga Kenangan Islam Tinjauan Teoritis dan Praktis, Jakarta: Kencana, 2010.

Julius, Hemawan, Membangun Design Sistem Informasi, Yogyakarta: Andi Offset, 2005.

Karim, Adiwarman A., Bank Islam Analisis Fiqib dan Keuangan. Jakarta: Raja Grafindo, 2004. 
Pengembangan Sistem Informasi...

Kendall Keneth E, Kendal Julie E, Analisis dan Perancangan, Edisi lima, jilid 1, Jakarta: Gramedia, 2006.

Kuncoro, Mudrajat, Manajemen Perbankan Teori dan Aplikasi, Yogyakarta: BPEE, 2002.

Majelis Ulama Indonesia, Himpunan Fatwa Dewan Syariab Nasional, Edisi Kedua, Jakarta : MUI, 2003.

Mcleod, Raymond, Sistem Informasi Manajemen, Jakarta: PT Prenhallindo, 2001.

Muhammad, Abdulkadir, Hukum Perikatan, Bandung: Citra Aditya Bakti, 2000.

Muhyuzir, T.D., Analisa Perancangan Sistem Pengolahan Data, Cetakan Kedua, Jakarta: PT. Elex Media Komputindo, 2001.

Mulyono, Sri, Teori Pengambilan Keputusan, Jakarta: Lembaga Penerbit Fakultas Ekonomi Indonesia, 1996.

Muslich, Ahmad Wardi, Fiqh Muamalat, Jakarta: Amzah, 2010.

O’Brein, James A., Pengantar Sistem Informasi, Jakarta: Penerbit Salemba 4, 2005.

Saeed, Abdullah, Bank Islam dan Bunga, Yogyakarta: Pustaka Pelajar, 2004.

Sidharta, Lani, Pengantar Sistem Informasi Bisnis, Jakarta: P.T. ELEX Media Komputindo, 1995.

Sjahdeini, Sutan Renny, Kebebasan Berkontrak dan Perlindungan Yang Seimbang Bagi Pihak dalam Perjanjian Kredit Bank Indonesia, Jakarta: Institut Bankir Indonesia, 1993.

Suhendi, Hendi, Fiqh Muamalah, Jakarta: PT. RajaGrafindo Persada, 2010.

Suryadi, R. dan M. Ali Ramdhani, Sistem Pendukung Keputusan, Bandung: PT Remaja Rosdakarya, 1998.

Susantio, Aspek-Aspek Hukum Perikatan, Bandung: Alumni, 1988.

Sutabri, Tata, Sistem Informasi Manajemen, Yogyakarta: Andi, 2005.

Turban E, Jaye Aronson, Peng-Liang Ting, Decision Support System and Intelegent, Yogyakarta: Andi, 2002. 